\title{
The Anathattractive s/State: A Marxist-Semiotic Analysis of the Discourse, Ideology and Practice of Neoliberal Workfare
}

\author{
John David Jordan ${ }^{1}$ \\ Department of Sociology, Manchester Metropolitan University
}

\begin{abstract}
This paper explores the complex semiotic entanglement between discourse, ideology and practical application surrounding the neoliberal welfare policy known as workfare. It focuses particularly on the Flexible New Deal - the version of workfare trialled in the UK from 2009 to 2010 under New Labour. The Flexible New Deal was a privately administered, for-profit, payment-by-results scheme which made receipt of welfare benefits conditional upon reciprocal activity - in particular, attendance at workfare centres for "re-training". This paper provides a Marxist-semiotic analysis of an actual Flexible New Deal centre, based on participant observation in 2010. This is framed within a wider analysis which proposes that an economic undercode dialectically interacts with class-racist ideology to semiotically sculpt the victims of structural unemployment into an apparent culture of pathological dysfunction - a theatrical illusion which nevertheless renders each unemployed person victim to a mendacious "rhyming up" with media folk-devils. In conclusion, this paper argues that via the term "underclass", individual states of poverty are transformed into the perception of a socially-cancerous, welfare funded, expanding state (i.e. nation) within the State. This elision of personal and plural, and transubstantiation of the processes of poverty into people, is marked by the novel signifier "s/State".
\end{abstract}

\section{Introduction}

\subsection{The UK's shift to workfare}

In 2009 the UK's New Labour government trialled a welfare scheme - the Flexible New Deal (FND) - ostensibly designed to re-insert the long-term unemployed (those unemployed for over one year) back into the labour market (Daguerre, 2004). While FND was cancelled in 2010 (replaced in 2011 by the almost identical Work Programme) it nevertheless marked a profound shift in UK social policy, rendering the old socialdemocratic aim of ameliorating the ravages of structural unemployment (EspingAnderson, 1990) largely obsolete, and introducing a new, neoliberal ideology - 'do something about the feckless unemployed' - to mask the deliberate expansion of the numbers of people cast into the 'reserve labour army'.

\footnotetext{
${ }^{1}$ Email: john.d.jordan@ stu.mmu.ac.uk

${ }^{2}$ In Marxist economic theory, the reserve labour army is a pool of unemployed individuals whose presence in the labour market both disciplines the employed through fear of the sack, and also drags down wage values, thus increasing the profitability of capitalist enterprises.
} 


\subsection{Introducing the anathattractive s/State}

In this paper I engage workfare from a Marxist-semiotic perspective. As such, I not only explore the empirical realities of such programmes, I also locate these within the wider structural, class, economic and discursive frameworks that generate the semiotic "theatre" in which the victims of structural unemployment are made to carry, symbolically, the blame for global economic catastrophe. I argue that the primary trajectory of workfare is the semiotic re-casting of the poor and unemployed as a pathological social limb that is illegitimately consuming resources belonging to "real" society. This, I propose, is achieved by a discursive legerdemain which elides the personal "state" of poverty with the sense of a growing, cancerous state within the State - the so-called underclass. I mark this elision with the sign "s/State". I argue that, once seconded to this s/State, individuals "attract" anathematisation via a media-inspired false-association with all other people in that s/state - most especially well-known media demons. This, I term the "anathattractive s/State".

While this process begins in the discourse of the wider arenas of neoliberal political-economy and the Right-leaning mass media, and draws upon the long-standing ideological distinction between the "deserving" and "underserving" poor criticised for centuries as a specious defamation of the victims of structural poverty (see Hazlitt, 1807; Mill, 1808; Marx, 1887; Piven and Cloward, 1971; Bourdieu, 1998), this study demonstrates how, within a workfare centre, the anathattractive s/State becomes performative, as individuals are subjected to disciplinary regimes that mortify, destroy morale, encourage hopelessness and prompt either surly non-cooperation or selfincriminating admissions of failure.

\subsection{Situating the study - dialectic economics, performative ideology}

While exploring workfare centres semiotically has been suggested programmatically by Goldberg (2001), that author's conception of benefits claimants being "wrapped" in symbols of profanity remains speculative (it is not clear, for example, how one would operationalise "profanity") and primarily located within the realm of discourse. In contrast, I explore how the economic realities of workfare centres - particularly their woeful underfunding caused by bidding too low for payments-by-results contracts create physical semiosis, such as group compression effects, defeatist body language and dressage performances through ritualised control. That workfare responds to wider neoliberal economic imperatives has also been proposed, signally, by Peck (2002) and Jessop (1993), who contend that workfare is intended to create docile, cheap, disciplined workers. However, in contrast, I demonstrate that while the "dull compulsion of the economic" (Marx, 1887: 516) drives the fundamental operations of a workfare centre, this is continually dialectically conditioned by the ideology of the "feckless prole", which downloads into staff attitudes, provider training materials and centre programmes from wider class-racist discourses. This does not create disciplined, docile workers; it forces internees - through threats of "sanction" (loss of benefits) and oppressive techniques of group management - to "perform" the role of feckless prole. As workfare centres inevitably fail in their primary official remit of forcing social categories unwanted by the labour market back into work, workfare centre staff psychologically re-task themselves as "social nurses" who, tell themselves that they are at least doing something to give structure and discipline to the lives of the feckless unemployed. This allows workfare centre staff to pretend that the meaningless programmes which they administer are 
PJOS 5(2), 2013

actually a useful form of therapy. This new mutation of the centre's underpinning dialectic is itself then re-conditioned by the dull compulsion of the economic as staff find that a patronising social nursing regime demoralises the internees, rendering their ever growing numbers easier to control. I make no argument as to the ultimate purposes of this social event; I only note that once the illusion of the anathattractive s/State has been established in the wider public consciousness, the unemployed become vulnerable to a wide range of potential trajectories. My exploration of these processes, furthermore, demonstrates how the often overwhelmingly complex-seeming vicissitudes of neoliberal globalisation can be directly connected to micro-level semiotics. For example, a workfare internee with hands placed over his face in utter desperation as he experiences the mortifying humiliation of being ordered to be positive, is not an isolated event, but the obverse of a vast reorganisation in the global economy. This programmatic reconnection of semiotics and political economy marks, firstly, a shift beyond the all too common tendency to view the ideology surrounding the "underclass" and benefits claimants solely in terms of the discursive and symbolic. As Anderson (1983) notes, this tendency falsely obscures the conditioning importance of the economic. Secondly, this study draws back from the other extreme - the approaches of, signally, Bourdieu $(2005,1998)$ and Skeggs (2004), which present virtually all aspects of society and culture in terms of "capitals" and "values" spent within "symbolic economies" for "symbolic profits". That approach, as Archer (1989) points out, just as effectively eliminates the meaning, and therefore independent significance, of the economic. This study will, in contrast, mark a reaffirmation, and demonstration, of the validity and importance of an economics based, Marxist semiotics.

\subsection{Flexible New Deal, workfare and disciplinary flexploitation}

FND was a form of workfare. In simplest terms, workfare is a social policy that makes the receipt of unemployment benefits conditional upon the performance of mandatory reciprocal activity ("conditionality" in welfare jargon). Conditionality usually, but not exclusively, encompasses compulsory attendance at workfare centres, re-training, caseworker interviews, lifestyle coaching, job-search, and sometimes mandatory work experience (Peck, 2001; Quaid, 2002). In 2008, the same year that a UK government report on foreign workfare schemes concluded that they were ineffective and prohibitively expensive (Department for Work and Pensions (DWP), 2008), UK government minister Peter Mandelson argued that: [the] welfare-to-work programme [workfare] makes the labour market flexible [...] It increases the supply of labour in the economy, its quality and its employability" (Dostal, 2008: 28). In one sense, workfare can thus be viewed as part of the ongoing neoliberalisation of the UK's labour force towards what Bourdieu (1998: 85) has described as "flexploitation". Flexploitation means the restructuring of work into wage-regimes which aggressively emaciate much of the subelite labour market's rights, wage-values, contracted hours and welfare benefits (Peck, 2001; Gorz, 1989). Flexploitation also means the installation of psychologically oppressive disciplinary working conditions - including the looming threat of workfare if fired (Harvey, 2011; Dumenil and Levy, 2004; Peck, 2001). However, the term neoliberal is misleading here. Arguments such as Mandelson's are based on neo-classical 
equilibrium theory which proposes that unemployment would mostly disappear if wages dropped low enough to allow entrepreneurs to employ more people (Deane, 1978). This is not new. Nor is it correct: Keynesianism, for example, was constructed upon an empirical analysis of the phenomenon of low wages and mass unemployment walking, miserably, hand in hand (Keynes, 1997). It is more accurate to say that workfare is an atavistic return to the old liberal ideology of disciplinary workhouses espoused by Bentham (2010 [1796], 1843) and Mill (1998 [1859]), combined with modern psycho-social theories of poverty and unemployment. The latter argue, variously, that welfare destroys self-esteem, retards active job-seeking, and corrupts entire locales by generating a welfare dependent, generationally transmitted, pathological underclass (see Kennedy, 1962; Moynihan, 1965; Nozick, 1974; Gilder, 1982; Murray, 1984, 1996; Mead, 1986, 2005; Wax, 2005; Schwartz, 2005). Thus, Bentham's intellectual descendent Lawrence Mead recommends workfare as a form of disciplinary socialisation capable of "dissolving" the "welfare class" (1986: 139). Again, however, while labour discipline has been widely proposed as a key marker of neoliberalism (see e.g. Overbeek and Pijl, 1993; Wacquant, 2010), Ernest Mandel (1971) explains convincingly that labour re-disciplining recurs regularly over capitalism's long sprawl. It is not, in other words, very neo. The primary goal of such intensified labour discipline is always to expand and control the reserve labour army in order to underpin a resurgence in capitalist profitability (ibid.).

It is not within the scope or intent of this paper to debunk the economics of workfare. Suffice to say that, as a means of moving the long-term unemployed off welfare and back into employment, it has been a spectacular failure (see e.g. DWP, 2008; Quaid, 2002; Sunley et al., 2001; Brett, 2003; Hohmeyer and Wolff, 2012; Kreiner et al., 2005; Peck, 2001, 1998; Piven, 1998; Bane and Ellwood, 1994). However, success is a malleable term. Capitalist poor relief has always demonstrated an impressive capacity to grow new veins from which to speciously extract ideological legitimacy and purpose. Primary amongst these, I argue below, is the pretence of acting as a socio-medical barrier against the cancer of the poor ( $c f$. Douglas, 1969), and it is this conceit, and its semiotic manufacture, which forms the bulk subject of this paper.

\subsection{Structure of the paper}

Section two of this paper outlines the broad semiotic frame which downloads into a workfare centre. This, as might be expected from a Marxist analysis, proposes not one semiotic view, but a struggle between differential class-based perspectives over the interpretation of the same sign-set. Section three adumbrates the first of these views - the ontology of late capitalism - outlining its structure and purpose. Section three outlines a Marxist response to this ontology. The fourth section engages the idea that workfare constitutes an amplification of pre-extant class-racist prejudices, and presents some novel conceptual tools with which to engage this defamation-game. Section five is an analysis of the semiotic-regime prosecuted in an actual FND centre. This is based on my direct experiences of working in the centre for a few weeks in 2010. The centre, and FND, are long defunct. However, based on extensive subsequent research I draw parallels with workfare more generally. The sixth section provides a concluding discussion in which I argue that workfare is a horrific exercise in waste management as art, the ultimate outcome of which cannot be fully known until it emerges in real time from the dialectical interaction between economic and class-racist "codes". 
PJOS 5(2), 2013

\section{A Marxist semiotics}

\subsection{Detecting macro-economics in micro-semiosis}

This study draws on three broad streams: Marxism, semiotics and symbolic interactionism - particularly the work of Erving Goffman. While at first these may seem disparate analytic threads, praxis begs to differ (see also Goldberg, 2001). Like workfare, neoliberal globalisation (workfare's economic parent system) is too often viewed primarily in terms of gross and abstract international forces and flows. While these latter are undoubtedly immensely significant, immensity itself can sometimes obscure the micro-fabric of neoliberal reality - i.e. the other business end of neoliberalism, where real individuals experience "the virtue of selfishness" (Rand, 1964) - as its victims. This study is concerned with the semiotic echoes that occur at micro-social levels subsequent to the movement of vast, global, economic eddies; and more particularly, how one key neoliberal apparatus - a workfare centre - acts as an amplification chamber for these reverberations. A workfare centre can have multiple purposes, depending on local political, geographical, economic and labour market imperatives. However, it always has the purpose of symbolically reprocessing its inmates into the cruelly and unjustifiably individualised destination of neoliberal blame-download.

Blame-download - i.e. making the victims of poverty appear to be to blame for their plight - is accomplished via aggressive semiotic regimes. These regimes, cannot, however, be separated from the immensity of the world-market. They exist solely as defamatory semio-disciplinary appliances in its service. Hence, to facilitate analysis, an innovative and creative schema is required that is capable of detecting the echoes of the financial big-bang (neoliberalism) in the cultural radiation (class-racism (Balibar, 1992)) leaked by workfare centres. Marx's work remains the primary and most profoundly incisive guide to the operation of the world-market and poor law operation today. Workfare, in many ways, takes every dire warning Marx made as to the oppression of the unemployed, and of the exploitation of low paid workers, and treats them not as a warning of what to avoid, but as a blueprint for what to do. There is nothing, furthermore, in the profound analytic over-view bequeathed by Marx which forbids linking macroforces to semio-disciplinary regimes. Quite the reverse: Marx himself details extensively the micro-discipline and discursive defamations prosecuted historically against paupers (1887, 1975a [1865]). Nor is the work of Erving Goffman somehow incompatible with macro-structural views. Goffman was acutely aware of the impact of wider economic processes upon individual 'treatments' (see especially Stigma) - and particularly the double-meaning of this word (see Asylums), which takes on a further level of significance in a neoliberal world where not only structurally engendered life-distress, but also poverty, is seen as a treatable, quasi-medical personal dysfunction (see, signally, Mead, 1986).

Between them, Marx and Goffman provide a basis for exploring workfare as a site of disciplinary semio-techniques, in Foucault's (1991) term. However, the Marxist semiotic element of this schema requires some further elaboration. 


\subsection{Multiaccentuality}

Too often, social semiotics (see Leeuwen, 2005) over-privileges the theorist's reading of a sign. The very word "reading", in this sense, implies an embedded semiosis which a properly literate academic "transcribes". Reading also implies - correctly - distance. However, to read a sign is quite different to being viscerally entangled with it, in situ. Eminent Marxist semiotician Velentin Volosinov argues (1986: 23) that signs possess "multiaccentuality". This means that different social classes engage the same sign, or collections of signs, from differential economic situations, thus experiencing them very differently. "Situation" within signs, from a Marxist perspective, is thus not merely a privileged reading of meanings, but an affective and class-based entanglement with them. It is more accurate, then, to speak not of reading signs, but of experiencing an entangled situation within what I will call 'sign-theatres' - i.e. presence within collections of signs that are drawn into a perceptual interconnection due to one's relation to them both experientially and performatively. The theorist's view is only one possible sign-theatre constructible from the available symbolic parataxis. We might also now add that different intersections of class, ethnicity, age, sexuality, ability and gender also colour not only sign-reading, but sign entanglement. There may be, in other words, multitudinous different sign-theatres being constructed out of any one situation according to differing personal assessments of, and sensitivities to, potential, implied or obscured semiosis. One might watch these, as an audience, or, in gradual degree, experience them, as an increasingly entangled participant. Each unique position imparts a different semiotic resonance.

However, while perspectives sensitive to social intersection are valuable, the current trend in the humanities towards intersectionality theory - which seeks to locate each individual within a complex, ever finer-grained nexus of cross-referenced social categories (see Hunter and De Simone, 2009) - is simply too coincidentally kindred to neoliberal ideology in that it reduces social complexity to individuals. Individualisation, as Bourdieu (1998) notes, makes it far easier for neoliberal regimes to present poverty and unemployment as self-authored. Following Engels ${ }^{3}$ (1976) [1886] I view this as, ultimately, not politically empowering, but de-politicising, due to fragmentation and desolidarisation - the very processes which, I will argue below, neoliberalism prosecutes via workfare centres. Consequently, following Volosinov, I propose that it is far more analytically and politically useful to view two broad sign-theatres as operating in a workfare centre: a proletarian one and a bourgeois one. To this is added the third: mine, the theorist's.

The theorist's interpretation still has an important role to play: "false consciousness" occurs just as easily at the semiotic level as any other. ${ }^{4}$ The very fact of a chasm existing between proletarian and bourgeois sign-reading means that there is a role for someone with an overview of both perspectives. The role of the - Marxist - semiotic

\footnotetext{
${ }^{3}$ Presciently, Engels makes the point that it is difficult to get anything done politically if everyone focuses on their own issue rather than on what we each have in common.

${ }^{4}$ According to Marxist theory, the underpinning processes of capitalism are, generally speaking, so complex and involved that individuals are often unaware of how these actually function, or why they themselves live in particular social and economic circumstances, or see things in particular ways. This is a "false consciousness" of the real productive relations within a society.
} 
PJOS 5(2), 2013

theorist is to reveal the sign-theatres in use in a field, to attempt to relate how it feels to be entangled within them, and also to reveal the extent of those entanglements with wider economic reality.

\subsection{Neoliberalism's Tenant}

Following Marcuse (1963) I view neoliberalism as an aggressive project of ontological re-structuration intended to embed the principles of self-interest and methodological individualism into every aspect of social, economic and cultural practice. Of the many socially corrosive effects that this process leads to, one is signally concerning: the restructuration of consciousness itself. Volosinov (1986: 13) argues that "individual consciousness is not the architect of [the] ideological superstructure, but only a tenant lodging in the social edifice of ideological signs". Contrary to the standard Western metaphysic of a fixed, indivisible self, soul or 'spirit being', Volosinov posits consciousness as the fluid and changeable product of a dialectic interaction with signs; and signs themselves as carrying ideological loads drawn from wider economic parameters. In the case of workfare, this constitutes a sustained attempt to re-form proletarian consciousnesses, generating a new, capitalism-friendly psychological tenant a bourgeois puppet-mind (the micro-version of a neoliberal puppet government).

This puppet-mind is an epistemological configuration designed to form unemployment paraphernalia into a sign-theatre of personal, not structural failure. If the unemployed can be made to accept this blame, they are both disappeared and also (at least temporarily) demoralised and depoliticised. The iconic example of this psychopathological entanglement is the attempt to convince everyone that structural unemployment is due to low self-esteem, i.e. due to a psychological malaise that retards efforts to seek work (see for example Layard et al., 1994). Whereas, a more radical - and accurate - interpretation of the same sign-theatre will see, rather, low morale, which is an exasperation with the situation. The difference between these two is one of blame locus i.e. where the responsibility for unemployment lies, in the system, or the individual. This is no coincidence; it is a fractal iteration of capitalism's foundation episteme: the erasure of awareness of the socio-economic totality, and the radical foregrounding of the isolated social unit (Lukacs, 1971).

\section{The epistemology of bourgeois rhetoric}

\subsection{The "underclass"}

A benefits claimant arrives at a workfare centre already the victim of aggressive negative signification. In Kafkaesque fashion, claimants wake up, not one day, but gradually, to the realisation that they are being transformed into social vermin: feckless, lazy, chav, scrounger, sponger, layabout and even "scum" (Littlejohn, 2008). These are special kinds of words. They are not only ideological in content, but also in form. As Marcuse (1963) notes, there is a way of (ab)using language - which we may broadly designate the capitalist episteme - that greases capital interests by locking ontological focus at the micro level, i.e. on the unit. This "focus-lock" distracts attention from - indeed 
anaesthetises - awareness of the systemic, macro-economic processes of exploitation that structure late capitalism (Jameson, 1991). This process has evolved (experienced a conditioning "functional selection" in Cohen's (1978) term) to aggressively sedate any implication of class exploitation, via a linguistic transubstantiation of macro level process into micro-level dysfunctionality - or, in the case of wealth, hardworking entrepreneurialism (see e.g. Donlan, 2008; Bhagwati, 2004). This is a species of magic trick, and the product is a linguistic alchemy which, falsely and bizarrely, allows a process to become a human being.

The effect is bedazzling. Social policy theorist Gary Bryner (1998: 48), for example, states that "The underclass is the most intense manifestation of urban poverty". The magic here is nearly literal: poverty, which is a state and, within late capitalism, the direct product of economic processes, "manifests" itself as people. This rhetorical transubstantiation of process into people, once performed, actively resits re-constitution into the truth: the trick was brief, effective, and easy to believe, but the rebuttal - Marxist theory - is complex, apparently tedious, and contrary to wider class-racist prejudices. And so the momentum of re-signification continues on, fallaciously transforming poverty-generating processes into personal dysfunction, failure or moral lack.

This magic trick is the base-conceit of workfare, but the perception it generates is already groomed into workfare centre staff by wider media and political discourse, long before they commence work at the centre. It is part of the miasma of late capitalism. The capitalist episteme aggressively functionally selects terms which can be used to talk of aggregates of individuals; terms that both emit class-racism, and yet also maintain a desperate focus-lock on the individual, not class (or heavens forbid structural) level. Scrounger and sponger, for example, can become scroungers and spongers to signify and defame the growing numbers of poor unemployed, and yet never imply anything other than a (swelling) collection of dysfunctional, lazy individuals. This is the foundation, and greatest achievement, of bourgeois class rhetoric. Its latest, more evolved iteration, is the media pseudo-signifier "underclass" (Gans, 1995). Althusser (1971: 5) states that some words are "the site of an ambiguity: the stake in a decisive but undecided battle." Underclass is very much one such battleground. For some Marxist writers, such as Wright (1997), the underclass is simply that group which is most utterly the victim of capital exclusion, whose labour power is worth exactly nil. Other scholars, such as Bauman (2000) and Pakulski and Waters (1996), however, have argued oxymoronically that although social class is - to them - no longer a valid sociological concept, nevertheless there still exists an "underclass". The effect of this word-game is the pseudo-erasure of class antagonism, as, drawing on Marx's (1975b) famous distinction between classes in, and classes for themselves, this leaves the underclass as, curiously, a class by itself, with no sense of how it got there. This opens a space for Right-leaning academics, politicians and the journalists to supply their own underclass creation myth: that it is self-authored through dysfunctional behaviour. This conceit has not become part of the capitalist episteme, however, through clear explanations of what the underclass "is", but primarily through the exploitation of a linguistic confusion; particularly so in the media. While lurid tales of "underclass" dysfunction generally employ the word formally as a noun signifying a group of people - for example in The Spectator's headline The Philpott case should prompt debate about Britain's underclass (Murray, 2013) - its actual meaning is usually drawn, liminally, and simultaneously, from its sense as an adjective signifying the dysfunctional activities of the subject of the story - in this case of Mick Philpott, whose botched arson accidentally burned several of his children to death. In a blurring of singular and plural almost too subtle to register, the individual media demon is presented as the underclass. His or her activities supply the adjectival meaning of "underclass", while the word's double sense as a plural noun speciously projects that individual's guilt 
PJOS 5(2), 2013

onto the wider poor. The point of this process is to "vanish" the poor and the unemployed by associating indigence with perverse cultural mores (see e.g. Gilder, 1982; Murray, 1984). In this Devil's arithmetic, the medium is not the message, but the factmanipulating massage.

\section{A Marxist-semiotic response}

\subsection{Anathattractive states}

Marx characterised the ideological attacks launched by the bourgeoisie against the working classes as class anathematisation. Work by social policy theorist David Byrne (2005) is useful here in constructing a Marxist semiotic response to this phenomenon. Drawing on some concepts from quantum mechanics, Byrne proposes that life trajectories might be mapped over time to reveal how certain personal circumstantial configurations tend to be "attractors" of certain economic states. For example, a single, 25 year old female from a poor background with a small child to care for is in a "state" that is very likely to "attract" poverty. Of course, Byrne does not mean in any way that such a person is responsible for the poverty they attract, but merely that a certain set of attributes renders them more likely to become a victim of peculiar structural and social injustices. This is true. We can usefully extend this idea to argue that certain states can attract certain forms of pariahisation. A poor female head of household, for example, exists in a peculiar [what I will label, fusing the words anathematisation and attraction] anathattractive state, obnoxiously targeted by media, academic and political victimisers. Variations in a poor person's life-facts can vary their anathattractive state. A poor female head of household, for example, might be moved to a municipal estate, and so draw the bizarre opprobrium so often directed against social housing tenants (Bourdieu, 2005; Jones and Novak, 1999).

Condemnation to an anathattractive state re-situates an individual. Signs become re-signified via the intermediation of this prejudicial social prism. But while this is a very personal fate, the process also rhymes its victims. This does not occur via a "levellingdown" of all attractors to an average of the total. Rather, as Marx (1975b [1847]) explains, one extreme factor is often over-emphasised so that it comes to osmote (in this case unjustifiably negative) signification to all of the others. Exceptional cases of indigent dysfunction, real or imagined, thus spring into media, and then public discourse, acting as mass-markers for the wider poor. Through a curious process of "referent fade", individual media demons - such as Alfie Patten, John Watkinson and Tracey Connelly - exist as individuals only ephemerally, before disseminating to become mass-markers of social collapse: the 13 year old dad, the millionaire benefit fraudster and even more vaguely, Baby P (Jones, 2011). ${ }^{5}$ Individuals semiotically expand into categories. Baby P comes to

\footnotetext{
${ }^{5}$ In 2009 Alfie Patten was - falsely - identified by the British media as the 13 year old father of a baby. Various newspapers picked up the story and ran with it, with The Telegraph signally exploiting the tale whilst simultaneously accusing the Pattens of exploiting it - using it to signify the current UK underclass buzz-concept of 'broken Britain'; even extending its disgust to Alfie's father, accusing him of also exemplifying broken Britain for having too many children (Woods, 2009). David Cameron commented on Alfie that "That's what's gone wrong and we've got to put it right" BBC (2009: 1), while Iain Duncan Smith
} 
stand for Baby-prole (Black, 2008), and any welfare funded "sprawling council estate" child thus becomes, potentially, a pitiable victim-in-waiting of the "feral underclass" and a potential new member of it (see e.g. West, 2009). As a signal example, Iain Duncan Smith (2008: 1) states of the horrific Baby P murder that "Dysfunctional family life lies at the heart of the problem". Both singular and plural are embedded in this statement. Applied in the singular, to the child's family, this is a glib understatement. But it is worded so mendaciously that it pseudo-pluralises, tarring a much wider, unconnected social group with guilt. Meanwhile, as Jones (2011) notes, the astonishing rareness of these cases, or instances of bourgeois equivalents, are largely omitted from class-racist political and media propaganda.

An anathattractive state is thus not merely a vulnerability to such ideological bile, but to these categorisations, and to a false and unjustifiable rhyming-up with a category's most infamous mass-markers. The concept of a broken society, which can only be achieved via this process of mendacious social rhyming, has been explicitly deployed by both Tony Blair (1997) and David Cameron (2009) to justify welfare "reform". This, in harmony with continued contrasting references to "hard working families" (Wheeler 2005) marks a sharp return to age-old attempts to split the poor unemployed faction of the working classes from the poor working faction (Handler, 1995); a resurgence described by Westergaard (1995: 118) as "the attrition of citizenship".

\subsection{Prolemes and fecklemes}

Mendacious rhyming is nothing new. And nor is it peculiar to welfare claimants: poor people have been subjected to obnoxious propaganda for centuries - indeed, millennia (see Exodus 5). However, under industrial capitalism, historically, this has been prosecuted by ideologically fragmenting the proletariat into multiple mythological "units", such as the politically dangerous, the thuggish, the overbreeding, the lazy, the uncouth, the stupid, the unclean, the diseased and the intoxicated. And also, occasionally, the decent and the loyal, where this serves capital interests. Just as Levi-Strauss describes the "units" of myths as being drawn from archetypal bundles known as "mythemes" (Hawkes, 1977: 44), so I describe these categorisations as "prolemes" - or mythological units of "prole". Bourgeois poor-law mythology focuses on its own sub-category of proleme, however: what I will term the "feckleme", or mythological unit of feckless prole.

Fecklemes include most of the general categories of proleme (omitting some, such as the politically dangerous), albeit refined into well-rhymed categories, such as "unwed

stated that Alfie's case "exemplified the point we have been making about broken Britain" (ibid.). It later emerged that Alfie wasn't the father at all. However, by then, 'the 13 year old father' had become an iconic signifier of 'broken Britain' all the same.

John Watkinson was a company director who falsely claimed over $£ 118,000$ in benefits. The Daily Mail claimed that he lived a "millionaire lifestyle" - this despite him not actually stealing "millions".

Nevertheless, the notion that the ranks of benefits claimants are stocked with cheats living the highlife has become a key weapon in the ideological war against the poor that is known as "welfare reform".

Tracey Connelly was convicted of allowing her partner Steven Barker and his brother Jason, to torture her 17 month old son Peter to death in horrific circumstances in 2007. This exceptional case was cynically used by right-wing British media to attack the wider poor, with, as signal example, Daily Mail journalist Helen Weathers stating that "Of course, nothing can ever excuse the unspeakable cruelty of Baby P's mother. But this harrowing Mail investigation lays bare how society's amoral and brutalised underclass breeds such monsters" (Weathers 2009). Iain Duncan Smith (2008: 1), meanwhile, exemplifying the bizarre fusion of singular and plural discussed in the above article, argued of the case that "Dysfunctional family life lies at the heart of the problem". While that is an astonishing understatement when referring to baby Peter's actual family, it is intended to refer - outrageously - to the wider poor, who did not murder the child. 
PJOS 5(2), 2013

mother" or "feckless father". However, unlike the average proleme, fecklemes are perceived to have committed a state-crime (in both senses, i.e. against the state and being in a personal state) under capitalism: i.e. allowing their dysfunction to keep them from the wage-labour market. The point of workfare, at least on one level, is to publicly anathematise them for this state-crime. As Marx (1887) notes, this is partly to provide a salient, disciplinary warning to others, and partly to mask the realities of structural unemployment - particularly its immense value to capitalism - behind a mendacious propaganda campaign.

\subsection{The proaretic code and the undercode}

Workfare operates on two levels, however - or rather, according to two codes - which clash and intermesh dialectically. The first of these is what Barthes (1988: 139) describes as a bourgeois "proairetic" code; that is, a code of narrative actions which implies a journey from inferior proletarian, to superior bourgeois, lifestyles and values. An excellent example is supplied by Stockport Council. As a council tenant I regularly receive letters from them emblazoned with the letterhead Stockport Homes: Transforming Lives. The implication of course is that the lives of council house tenants require transformation. The proairetic code, similarly, in-forms the ideology of workfare institutions. The second code - which I will call the "undercode" - is what, in more proper, Marxist terminology, is known as the dull compulsion of economic reality. The undercode grooms the actual operating practices of workfare centres. In the following section I will draw on the conceptual tools outlined thus far to explore how these two codes interact in a real workfare centre.

\section{The semiotics of actually existing workfare}

\subsection{Introduction}

This section will present a case study based on just over four weeks of participant observation in a private FND centre - anonymised simply as the Centre - in 2010. During that time I worked as a member of staff, ostensibly on a trial period basis, and participated in all of the major activities of the Centre. In addition to fieldwork observation, I conducted numerous discussions with staff and internees as to their opinions and feelings about the Centre and its operations.

\subsection{The Centre}

Welfare claimants interned at workfare centres are known as clients. As Goffman (1961) notes of this curious abuse of term, the internee is actually the thing brought in to be fixed; the real client is the authorities. And this is precisely how the staff at the Centre view the benefits claimants seconded to their institution: as fecklemes of various species captured on their "sprawling council estates" by welfare officials and brought in for reprocessing into "decent", functional beings. Not workers - because the staff rapidly 
realise that that is prevented by the undercode (i.e. lack of available jobs) - but, as a second best, into decent people. This, however, is an example of what Sartre (2004: 162) termed counter-finality: i.e. the institutional conceit of attempting to make internees decent is the hidden mechanism via which they are semiotically constructed as indecent. Condemnation to a workfare centre, in other words, marks descent into a profound anathattractive state: once in, every aspect of one's reprocessing is designed to attract evidence of belonging there.

Clients first arrive at the Centre - a small, cheap office suite in a multi-story office block in a medium sized British town - following the receipt of a "welcoming letter", oxymoronically inviting them in for a compulsory induction. The Centre runs three such inductions a week, on Tuesday, Wednesday and Thursday, with each induction attended by 15-20 new clients. These have been sent here by the job centre, and must comply on pain of financial sanction.

Clients arrive one at a time, as individuals - but the processing logic of the Centre is a fractalised replication of the concept underclass with its peculiar elision of singular and plural, and so arrival is merely the commencement of a process of "negative individualisation". This, the real-life corollary of Libertarianism's version of "negative liberty" (leaving people alone to make a profit) (Berlin, 1958) means the counter-intuitive aggregation of capitalism's victims into groups for the purposes of deliberate demoralisation via regimes of psychological isolation. First, however, comes their semiotic fusion. As Marx (1887) explains, capitalism tends to compress the poor (e.g. in factories, prisons, workhouses, cramped dwellings and towns) under the watchful eye of supervisors and state agents. Compression (conveniently for capitalism) also facilitates an increase in the semiotic density of the poor - i.e. physical closeness engenders the blurring and cross-signification of factors such as attire, lifestyles, houses, accents, education, job-types, illness and work histories. When rhymed up, as discussed above, with iconic mass-markers, this renders poverty more easily re-presentable as a lifestyle choice, and not what it actually is: a lifestyle foist. Semiotic density in turn increases the anathattractive magnetism of a compressed group, so that even tertiary membership - e.g. finding oneself unemployed for the first time in decades - rapidly catches an individual in its gravity, accelerating the process of semiotic mergence with the anathattractive symbolic body.

When clients arrive at the Centre, they undergo a very deliberate extraction from their habitual cultural networks. The Centre's procedures are firmly founded upon the premise that those networks must be, by definition, dysfunctional - because otherwise clients would be in work. "Mending" that dysfunction is believed, by the staff and the programme's designers, to begin with a "tough love" forced insertion into a healthier, more disciplined culture. This begins with shaming, as it is felt that clients need to learn indeed to come to feel - that "sponging" is unacceptable behaviour. However, the Centre programme never actually goes beyond this. This is not a surprise to the internees; most know, from previous experience of the welfare system, that they are unlikely to find any actually useful help here. Rather, they know - even if they do not consciously express it in these terms - that their role here is going to be largely performative; the Centre will constitute a "theatre of shame" in which staff and clients will play out a ritual blamegame, which clients will - must - go along with in order to remain eligible for their benefit cheque. And simply arriving at the Centre for the first time is the first performance, because it is shameful in itself to have to turn up and play. However, while this shame-game is merely the product of the proairetic code, right from the start, when internees first arrive, the undercode is already emitting symbolic indications that the clients are by no means a random selection of dysfunctional, sponging misfits: They are almost all male, middle-aged and working class. Most are former tradespeople, such as 
PJOS 5(2), 2013

roofers, builders or bricklayers. Many of the internees can interpret these signs. It is clear, for example, that particular ages and types of people are unwanted by the labour market and involuntarily now surviving in dire circumstances. The staff, on some level, know this too - but what Macnicol (1994: 30) has described (in relation to council estates) as the "concentration-effect" makes it difficult for any new clients to be seen as anything but yet another underclass feckleme. After all, they, on the whole, share broad accents, manual labour backgrounds and working class language codes. And they are likely to not want to be here - and to very much resent the patronising proairetic ideology of the staff. So they share glum body language, hostile attitudes, and the behaviour of embarrassed, harassed beings. They also are here, obeying - so they share also what Joel Handler (1995: 86) has described as a state of being hostages to welfare regimes. Hostage status significantly affects older male or younger female claimants, as they are more likely to have dependants to support and much to lose if sanctioned. The outcome is that what was a product of the undercode - the demographic make-up of the client base - becomes, via the concentration-effect, fodder for the proairetic code: individuals become "them", a type, to the staff.

This self-feeding conceit begins as soon as clients arrive. FND was a privately contracted payment-by-results scheme. Payment-by-results contracts have been described as "races-to-the-bottom", due to bidders desperately seeking to undercut their rivals' proposals (Murray, 2013). This sometimes means - as in the case of the Centre - that the bid made is so low that it constitutes not a race, but a suicide jump to the contract-bid bottom - giving a whole new meaning to "suicide bid", because it is simply impossible to fulfil the contract within the proposed budget. The Centre is therefore far too small for its client base. A tiny kitchen, for example, is the only available waiting area, and so it is always crammed as internees await their next redistribution according to the Centre's deliberately vague and arbitrary temporal regime. When internees first arrive at the Centre they are instructed by staff to "go back and wait in the kitchen. We'll come and get you when we're ready". (Internees are also instructed to "get yourself a brew". As Goffman (1961) notes, making oneself a drink is a coded signification of belonging in itself, as only belongers make their own drink). Internees cannot avoid referencecontamination as they are physically compressed into this tight waiting space. When the staff do come to collect them, they thus find a "prole-clot", tightly rhymed across multiple symbolic spectrums. Firstly, proximity: compression creates impression. Secondly, via clothes. Attire is one of the oldest means of rhyming individuals for purposes of segregation, because it is so instantly visually effective (Jewish Virtual Library, 2013). Clients arrive in what the Centre staff call "their home clothes" - which, inevitably, are often cheap and well-worn. They - the staff - view this as indicative of lack of client work attachment - as if home exerts such a powerful lure that clients cannot - yet - bear to don work attire. However, this is not work, and for many manual workers casual clothes are their usual working attire.

The prole-clot is further rhymed by age, posture, temperature, language and attitude. Courtesy of the UK government's misguided bringing together of multiple social need-streams, a tiny fraction are homeless, and thus are unwashed, and smell. And so the group smells. A tiny fraction smell of alcohol, and so the group smells of alcohol. If one swears, the group swears. If one sweats profusely, the group sweats profusely. The heat 
of the room accentuates the aroma. Individuals merge into a single institutional entity, each part of which constitutes a rhymed up fractal of the total monster. None can escape its anathattraction; its imposed epitaph is all for one, one for all. This monster - a temporary fiction of the undercode - is then delivered by prodding, breath-holding staff, into the aptly named induction room.

The induction room is a medium-sized, bare-walled office containing only cheap desks and chairs, and at the front of the room, standing like a monolith, a conference pad bearing the hand written commandments of the institution:

1. Arrive on time.

2. Arrive Sober - absolutely no drink or drugs.

3. No foul or abusive language.

4. No smoking in or around the building.

5. Swearing, violence and aggressive behaviour towards staff will not be tolerated.

6. Be positive at all times! (;)

While Staff prepare the induction paraphernalia - forms, pens and worryingly fat, precollated personal information files - clients are left to meditate upon this monolith. Its rules are a "prole-socket": an institutional receptor designed to fit what the underclass are perceived to be in bourgeois mythology; or, what is known in rhetorical studies as a connative code, i.e. one that constructs an idealised addressee (Eagleton, 1991). I soon learn, in fact, that most of the internees have long and respectable work histories.

The session "leader" is terrified. She has no training, being herself a low-paid former administration worker who would otherwise be unemployed and would rather be otherwise employed. Nervously, her well-rehearsed but still badly performed induction speech commences, as always, with: "You are here because you have failed..." It goes on: "...to find work in the past year..." but as internee bodies slump, hands go to faces like Munch's Scream and breathing becomes audible, the trite platitudes of the proairetic code dissipate amidst physically visible morale-fade. You have failed is all that the institution really wants to say.

Unbelievably, a four to five hour grilling follows, prosecuted via speeches, harangues, intrusive forms, interrogation, pseudo-tests, embarrassment and humiliation, all to uncover what it is inside a client - what moral lack or psychological malfunction that is causing their failure; a form of petty psychologism that might better be characterised as an extension of demonology and exorcism (see Danaher, et al 2000). A half-hour failure-lecture comes first. Internees are infanticised: (primarily) middle-aged people are placed back into a classroom, with desks and a teacher, perhaps for the first time in decades, addressed patronisingly by their first names, told how to sit and behave, and must ask permission to go to the toilet (permission often being refused). Stress positioning is deliberately employed: forcing middle-aged, working class people (the group most affected by the illnesses and ailments inflicted upon workers by capitalism (Black et al., 1990)) to endure long periods standing in corridors, sitting in uncomfortable chairs, hunched over computers or baking in sweltering offices. "It's meant to be a shock for them," a more experienced staff member advises me. (Cf. Klein's (2007) examination of neoliberalism's employment of the "shock doctrine".)

The induction speech is followed by two hours of form-filling. Welfare demonology requires repetitive "data-chanting" - that is, providing the same information over and again in countless forms, or in person, within and through each eleemosynary institution attended, and at each stage of attendance (see also Herd et al., 2005). Personal details, work history, qualifications, experience, what jobs they would "ideally like to 
PJOS 5(2), 2013

do", what they could "realistically" do... All of this information is already extensively detailed in the internees' personal files, supplied (from previous data-chanting sessions) by the government welfare agency named, in literally Orwellian fashion, the Job Centre Plus. But now internees must chant it again.

The general gist of these forms is proairetic: they are designed to draw out why the client is unemployed and so help plot a cure. Blame ("barriers" in Centre jargon) is assumed to be moral: idleness, criminal records, debt, work-on-the-side - or quasimedical: alcoholism, psychiatric problems, depression, drug addiction, and most of all, low self-esteem. A major ethos of the Centre, as the manager explained to me, is to "identify these barriers and assist clients to overcome them". They must, therefore, firstly be made to confess them. The forms demand a detailed confession of all barriers. There is no innocence option - that would mean leaving forms incomplete: a sanctionable offence.

A questionable clause in one form grants legal permission for anything an internee declares in these paper confessions to be passed on to "any third party" if the institution's parent contractor - a major US corporation - so chooses. This astonishing demand does not seem legal - and probably is not. In addition, there are some here who are intoxicated or suffering confusion or learning difficulties. Others are merely hostages; but all are forced to sign this clause under aggressive threat of sanction. This adds to the general mortification of the internees yet another flay: a stripping of legal rights, i.e. of their minimum citizenship. By institutional practice, which is probably, in reality, no more than a time wasting exercise, internees thus become what the staff perceive them to be: sub-social.

Each week at least one person is forced to raise a hand and confess illiteracy. No protocol is emplaced in anticipation of this incredible embarrassment; the staff anticipate most of the group to be poorly literate. The illiterate too, however, must make their mark on the forms, dubious legal codicils and all.

Next, internees are required to complete a form called a "job-matcher". This timewaster contains around fifty phrases, including:

I like to work with animals. I like to sing and dance on stage. I like to write. I like working with people. I don't mind working at heights. I prefer to work on my own. I like working on the telephone. I don't mind heavy lifting. I like to work outdoors.

Internees must tick columns indicating how much each phrase applies to them, and then tot-up the columns to see which type of job they are most matched to. Of course, they could have just been asked what employment they preferred or were qualified to perform - and in fact, in a previous form just were asked. But the point of the job-matcher, at the proairetic level, is to imply that people might be workless because they are confused about what they want to do, or because they are applying for employment which does not match their skills and experience. The results border absurdity. Some internees are advised to consider jobs such as zoo worker, actor or writer, while former bricklayers, roofers, and lorry drivers find, wryly, that they are best suited to work as bricklayers, roofers or drivers.

Another form asks if the client would like help disclosing a criminal record. Those who tick yes are advised simply never to mention it to an employer. Similarly, those with no qualifications or experiences are told to make them up, as "no one will ever check". 
At the undercode level, however, the point of these forms is simply to waste time: a certain amount of client contact hours must be contractually fulfilled, but real employment training is fantastically beyond the budget of a workfare centre, hence, such institutions are structurally groomed to engage in time wasting. The information in these forms is mostly never referred to again, beyond this day.

Isolated incidents of mortification resistance do occur, such as arguments, refusals and protests. Staff use these as a disciplinary weapon: trouble makers who are kind enough to identify themselves are made examples of, either by dismissal from the Centre (a direct route to a sanction) or by being threatened into silence. Internees who make reasonable requests to leave early to collect children from school are refused permission. They are then forced to ask for permission to use their own mobile phones to arrange lastminute child care. Staff cynically employ the control protocol that the humiliation of one is the humiliation of all, recommending its practice to new staff members.

Next, the group is subjected to a computerised psychometric intelligence checker, regardless of extant qualifications - and regardless of ability to use computers. Those with little computer experience are thus made to appear stupid. The results of this test are regularly referred to from this point; they go right at the front of a client's manual file, and dictate their perceived level of training and support need.

After two to three hours of induction, just as the group begins to reach the limits of patience and threaten to coagulate into solidaristic resistance, the institution plays its trump card: it ominously disaggregates the internees, marching them in cohorts of five into a claustrophobic office for their first "case worker interview". These onerous "culpa session" interrogations (Goffman, 1961), where internees are pushed to explain their failed state (a micro-fractal of imperialist neoliberal warmongering ideology), constitute a powerful negative individuality experience, with five separate mortifications occurring consecutively within the same room. Goffman (1990) argues that the stigmatised are acutely alive to the possibility of embarrassing disclosure leaks in any social setting, and that this is itself a psychologically stressful state. At the Centre, however, mortificatory disclosure is unstoppable as "information spills" occur regularly: files left open revealing intimate information, CVs stored openly on public computers, obnoxiously loud phone calls about you, personal details left on notes and computer screens, inevitable gossip and sharing of data, and, worst of all, the very public and open discussion of one's most personal problems. Staff call out to one another across the room, over the internees they are discussing: "How long is someone on the sex offender's register for?" "What's the number for Alcoholics Anonymous?" Just as films have non-diagetic sounds, that the characters cannot hear, so staff communicate with one another as if the clients are unable to hear themselves being spoken over in this way. Not only is this profoundly embarrassing in itself, but, according to Goffman (1961), witnessing the demeaning of others in your cohort is itself psychologically mortifying.

Suitably softened up by hours of physical and psychological stress-positioning, the internees now find out what the panopticon has evolved into in the neoliberal age: the disciplinary interview. It is sometimes forgotten (due to its foucauldian overuse) that the panopticon, although in part a horrific poor-house fantasia (Bentham, 1791), was envisioned not simply to watch, but to psychologically affect as a disciplinary technique (ibid.). Surveillance is merely watching; to have an "observer effect", it must push oppressively upon the watched, creating dread. But in a mass surveillance society, "dread-fade" is inevitable, as populations come - to some degree - to psychologically adapt to scrutiny. In such a regime, watching must again become physical and present in order to "dread-up" the experience. Disciplinary interviews punctuate their victim's lives with inescapable ritual denigrations. The point is not so much the denigrations themselves, but how cheaply (undercode imperative) and effectively they fill the days in 
PJOS 5(2), 2013

between them with waiting-dread ( $c f$. Kafka, 1953). This onerous temporal regime attacks morale and corrodes social agency via a "looming effect". For the looming effect to work, however, the interviews must be dreaded. Signing-on at the job centre or attending a workfare caseworker interview are actually meaningless in content; it is their psycho-positioning in time that matters.

The Centre's interview room is all about dread. It is structured to situationally strip internees: while staff are seated in comfortable office chairs, obscured behind tables, bristling pen-cups, computer screens, and administration detritus, internees squirm at the side of the desk in cheap plastic seats, their whole poor body rendered naked to official and room - scrutiny in a shame-theatre for one. Internees sit in silence, or emit awkward chit-chat. Staff face their computer screens, choosing when to look at or address the client. Even the control of eye, and human, contact is thus embedded in office layout.

A computer generated semi-structured interview is used for this interrogation - and answers are recorded digitally, and sent to the Centre's parent contractor in the United States for further analysis, and in time, instructions.

The interview questions are another prole-socket, beginning, always, with "Why are you unemployed?" This and subsequent questions are intended to inject the venom of the bourgeois ideology of personal failure into each internee's self-consciousness. The capitalist episteme is incapable of articulating a reason why an able-bodied person would be unemployed. It can only view them as a feckleme (see Mead, 1986; Gilder, 1982). One interviewer takes pleasure in forcing clients to relate their entire average day to him. Any time not spent job-searching is then highlighted as unacceptable idleness.

To the staff, this process of ideological inoculation (against structural consciousness $^{6}$ ) appears like medicine. As Goffman (1990) explains, the stigmatised are often groomed by experience into concocting pseudo-perspectives on their predicaments that fit wider social expectations. So while some internees do offer mortification resistance, many others scramble awkwardly to offer an explanation of their unemployment which falls in with the proairetic code. Debt, alcoholism, drug use, ill health, poverty, depression, family breakdown, hopelessness - all of which could be caused by unemployment, rather than be causes of it - become vocalised as awkward "troubles" which are then discursively, and dubiously, elided with employment status. Elision itself elides, falsely, but with inevitability, into causation. However, the moment the internee capitulates in this way, they become immediately hooked into the institution's "looping" (Goffman, 1961) ideology: these admissions are seen by the interrogator as a breakthrough, and more and more probing questions are levelled to attempt to make the client draw out and face (exorcise) their barrier (demon). The

\footnotetext{
${ }^{6}$ According to Marxist theory, poverty and unemployment in industrial capitalism are, by and large, the products of economic processes operating at the macro-structural level. This is in contrast to arguments that indigence is primarily the product of individual lack of effort. The Marxist theory of false consciousness proposes that individuals can be distracted from the realities of structural poverty by being ideologically indoctrinated to believe that poverty is self-caused.
} 
internee, in turn, is forced to continue to build their story, giving the interrogator precisely what they want to hear. The story "pools" - growing bigger and bigger - and the interrogator falsely perceives this as getting deeper and deeper into the internee's dysfunctional psyche and lifestyle. And then at the end, the charade collapses. The staff are only playing at being social nurses; in truth they are cheap, ex-admin workers, and their only profferable solution is trite advice: "Well try to get out more, that'll cheer you up." "Try to spend less, that'll save some money."

From now on, these disciplinary interviews - which last around twenty minutes will occur every two weeks. At each interview, the internee is expected to have progressed in overcoming their barriers. If not, the looping occurs again - internees have to spill more guilt on themselves, going further into pooling a picture of dysfunction to feed the expectations of the case worker. The longer this charade goes on, the more it seems that the barrier-demon is real - after all, so the proairetic ideology suggests, if it wasn't, they'd be in work, wouldn't they?

Next, the internees begin six weeks of "training". All of the usual welfare timefillers are employed in the Centre's training regime: CVs, covering letters and interview techniques. Most training, however, is intimate. Hygiene is highly emphasised: one must wash properly and clean one's teeth: "Body odour annoys co-workers and bad breath puts off potential employers". This training is not simply delivered, however: internees selfmortify by being forced to offer suggestions - and they build the list that is then written onto the white-board:

Taking a shower. Washing armpits. Using deodorant. Cleaning teeth. Wear clean clothes and underwear. Iron your clothes. Wear a tie. Don't slouch. Don't swear. Speak clearly and politely.

Don't be aggressive. Don't be racist. No sexual touching.

Outlook is covered too. Life-coaching sessions encourage positive thinking. Positive words are collated on the whiteboard. Positivity is compulsory - an indicator, argues Goffman (1961), of a total institution.

However, despite the obnoxious morale-corrosion engendered by such training, the most onerous aspect of the Centre's regime is something else, something that does not last as long but is more intense: the psycho-physical stress positioning known as jobsearch. These sessions involve a prole-clot of around twelve clients crammed into a tiny, humid computer room, forced to repetitively trawl the Government's jobs.gov website, reviewing the same, mostly long expired vacancies, over and over, under the close supervision of a staff member. This includes many internees with no computer skills, some with poor or even no English, some illiterate, and in my time, at least one who was clinically blind.

If clients complain that there are no jobs, they are met with the Devil's arithmetic. This states that there are two hundred thousand jobs on the jobs.gov website, and only one of you. But that list is for the whole country. In fact, there are many of you for every vacancy, and you are by no means top of the wanted list. Many of the vacancies, in fact, are bogus: commission-only sales, or tricks to harvest job-seeker details for data to sell, or to swell employment agency rolls.

All of this, however, becomes progressively moot. The centre makes money when clients are gotten back into sustainable work. The clients are not getting back into any work, because the labour market does not want them. The Centre is not, therefore, making any money. However, there is another possible source of income. When clients are referred to the Centre - which means no more than that the Job Centre Plus enrols them on a computer system and sends over a corresponding bundle of documents - the Centre attracts a small "referral payment" (DWP, 2009). The anthropologist Claude LeviStrauss (1961: 287) reports that the Brazilian Nambikwara people, although much 
PJOS 5(2), 2013

preferring meat, often find themselves forced to survive instead upon "grasshopper pie" grasshoppers always being readily available. Similarly, the Centre begins to survive on the grasshopper pie of referral fees, not the meat of job outcomes. This means that they need as many grasshoppers as possible. The Centre thus begins to accept as many client referrals as are offered - and is soon, according to the manager, receiving fifty to eighty new ones every week - all of whom need to be processed, interviewed and trained - for a period of one year in this tiny office. The Centre is overwhelmed. There is a locked storeroom containing mail-bags full of unopened referral letters -i.e. people who are on the system, who have attracted a referral payment, but who have never been called in even for an induction. A substantial ambition-fade occurs. Over a period of weeks, as client numbers reached institutionally catastrophic proportions, training dropped from a compulsory six weeks, to four weeks, to two, to two days a week, to, by the time I left, only if they really need it. This is the undercode, pushing an inevitable breakdown; but capitalism-proper has always done this - and always retrieves from this a dialectic engendering of the next phasal mode of pauper exploitation. In other words, FND served its purpose as the storage phase of the industrial reserve army cycle, compressing the victims of structural unemployment into a disciplinary prole-clot and consequent anathattractive state, viciously defamed by media, political and even academic discourse. FND's inevitable failure, which was not caused by client resistance, idleness or dysfunction, but by simple economic realities, then groomed class-racist calls for a much harsher disciplinary re-socialisation of the feckleme underclass: preferably in forced work-for-benefits schemes (see National Audit Office, 2012).

\section{Concluding discussion}

\subsection{The anathattractive s/State, prole-control and the workfare dialectic}

The fear that the numbers of prolemes might expand and infect real society was aggressively exploited by New Labour via its social exclusion rhetoric (Cameron and Palan, 2004; Byrne, 2005) - a fiction cynically deployed to mask the capital exclusion engendered by neoliberalism. This feckleme tale generated and intensified council estates as anathattractive sites, so that condemnation to grinding poverty became semiotically resignified into a dysfunctional life choice; a neat, fast-breeding fusion of undercode and semio-ideology. This symbiotic, semiotic conspiracy downloads into all of the apparatuses of state-neoliberalist prole-control: courts, prisons, probation offices, asylumseeker centres, housing authorities, social work offices, job centres - and workfare poorhouses. Each such apparatus, however, is constructed to manage a peculiar brand of proleme, adapting its semio-regime accordingly.

"Brand" is used consciously here to mean the creation of a brand through branding - a literal fate, in the past, for many paupers (Marx, 1887: 515). Historically, the problem with paupers (for capitalism) is that the difference between them and the lowest paid workers is rarely financial (Spicker, 1984; Digby, 1989) - a fact still in evidence, for example, when it is argued in disgust that some benefits claimants earn as much in welfare as full-time workers do in wages (see Cameron, 2013). Seen rightly, this actually 
means that some workers earn merely benefits level wages; a shocking reality which poses a powerful challenge to the ideology that work lifts people out of poverty (see e.g. Gilder, 1982). To mask this inconvenient discrepancy, and to neutralise it as a rallying point for anti-capitalists, an imaginary moral difference is constructed between the deserving poor and the fecklemes via media, academic and political anathematisation (Marx, 1887). An imaginary moral lack, however, necessarily has no physical manifestation. Achieving an effective- and affective - foregrounding of paupers as individual failures therefore requires marking; or what came to be known in poor-law practice as "badging". Although darkly ironic, disappearing structural poverty is regularly achieved by constructing, and radically foregrounding, the feckleme.

The literal badging of paupers under capitalist regimes began in the $15^{\text {th }}$ century (Spicker, 1984) - and this continues, for example, in making workfare victims wear orange tabards as they clean streets (Piven and Cloward, 2001). However, as Bentham knew - indeed recommended (Spicker, 1984) - badging can occur via other means. One such important means is displaying paupers in shame-theatres, such as stocks, labouryards, work-schemes/placements, workhouses (Marx, 1887; Burnett, 1994), newspapers (Atkinson, 2013), published claimant rolls (Littlewood, 2013) - and workfare centres. Noting the almost total failure (in fiscal and job-outcome terms) of European workfare, Bret (2003) wonders what its rationale could possibly be. There are some important economic answers to this, as Peck (2001) and Jessop (1993) have demonstrated, such as super-exploitation $^{7}$ and labour discipline. But on another systemic level, workfare's purpose is to badge its victims: to symbolically sculpt them into underclass fecklemes and so download into them the blame for neoliberal globalisation's failures - and then to stock them in shame-theatres for ritual castigation. There is also some sense of magical panic here - of terrible, impotent fears, of approaching, hostile, almost supernatural market "forces". And so, much as ancient South American tyrannies might have attempted to repel a plague by desperately slaughtering captives in grim stone temples (another form of horrific social art), so the economic plague of neoliberalism is addressed by tormenting individuals in grim workfare centres.

The real-konstruktion of a workfare centre, however, is not simply the product of class-racist Benthamite malefactors. These malicious social architects are lurking, but more is at play. Three key streams evolve into a workfare centre: the disciplining of the victims of poverty, their semiotic denigration, and the basic logistics of running a cheap prole-control apparatus. Although often overlooked (perhaps due to its lack of analytic glamour) the most important of these is the latter. Every prole-control apparatus will, with dull inevitability, adapt to its budget. The neoliberal undercode, however - particularly the quasi-religious faith in marketisation (Harvey, 2011) - is not so much a dull, as a dullard compulsion. It eggs-on suicide bid franchises that have little hope of breakingeven without breaking the rules. And payment-by-results constitutes the most vexatious of all (neoliberal) greed-dreams. Such cargo cult contracts, applied to welfare, cannot long resist the sharp reality-slap of the structural causes of unemployment. Failure in terms of job outcomes is inevitable, short of enforced slavery ( $c f$. DWP, 2012) or an economic upturn (see Peck, 2001). Referral fees, intended to tide-over a centre until the magic cargo materialises, merely vitiate the moral hazard of client loading, i.e. of taking on more clients than the centre can handle, just to provide a grasshopper pie income.

Training, and the other two workfare con-words, help and support, are laughable

\footnotetext{
7 "Super-exploitation" is the process of extracting much higher than average surplus labour value from workers (see Mandel, 1971 for an excellent explanation).
} 
PJOS 5(2), 2013

euphemisms for, at best, time-wasting, and at worst, class-racist social re-education. Such a situation, however, is not a spontaneously generated shambles but the product of deeply unhealthy dialectic. That a workfare franchise has even been taken on indicates that the proairetic code had already permeated executive perceptions: Without the pathologising conceit that the unemployed are fecklemes, who, with disciplinary re-socialisation could be re-inserted into the job market, there is no business rationale for payment-by-results workfare. The horrific social art side-project of neoliberalism - to semiotically sculpt its victims into an anathattractive state - is thus not a creation of workfare centres, or prejudiced staff, but indicative of a wider socially miasmatic illusion.

This illusion emerges as a twisted ideology, parasitic upon the ongoing material reality of capital exclusion (Miliband, 1989; Westergaard, 1995). The primary site of semiotic class struggle is the process of poverty itself: The semiotic border between the wealthy and the very poor is very real, courtesy of an axiomatically grossly uneven distribution of options, commodities and services. When, as under neoliberalism, a privileged elite actively appropriate for themselves an ever greater share of social wealth, that border shrinks back around them. It may even take on proportions of obscenity - i.e. the trappings of plutocratic hyper-wealth contrasted with starvation poverty. This process lends itself to an awakened materialist consciousness - but also to a counter-revolutionary ideological parasitisation: Rather than an ongoing project of aggressive capital withdrawal, it is possible to pretend that it is the poor who are, by the vice of their own laziness and dysfunction, expanding like a cancer. This is the class-racist illusion that downloads into a workfare centre. But with this conceit comes also - indeed first - its material, dialectic base: capital exclusion. The capillary withdrawal of wealth from social welfare axiomatically renders prole-control a minimum-budget project. The neoliberal counter-revolution thus evolves fractiously within the hothouse of a workfare centre. Staff soon learn, for example, that client dressage does not lead to employment. The only source of job-purpose and self-worth which staff can retain after this grim epiphany is to engage in the fantasy of being social nurses fighting the good fight on the front line of the struggle to cure fecklemes of their social sickness. Thus, a meaningless, pointless workfare scheme becomes psychologically transubstantiated into an institutional mythology of giving the clients structure and discipline. The content of delivery becomes irrelevant. Job-outcomes become irrelevant. Pedagogy and dressage themselves become self-purposing ( $c f$. Bourdieu and Passeron, 1990; Foucault, 1991). Indeed, the more pointless, menial, repetitive and demoralising the activity the better, because this is seen as at least preparing internees for the comparable conditions of menial labour - as if making the unemployed perform work-like activities might, via sympathetic magic, attract a job.

The undercode, however, rolls on with dull enthusiasm. Cheap prole-control, prosecuted via forced prole-clots and corresponding regimes of class-racist dressage, inevitably prompts the dialectical emergence of a new systemic worry: resistance. The agency of individuals can be conceived of as what Georg Simmel characterises as spheres of effective social action (Manning, 1992). Spatial compression of the poor thus carries with it the danger of a coagulation of these spheres into a tightly-knit and therefore potentially politically effective "social foam": i.e. strikers, rioters, revolutionary fronts, unions, political parties, gangs, alliances, criminal organisations, close communities, 
resistance or even guerrilla organisations. Hence, just as neoliberalism eliminates structure discursively, so also does its application evolve to eliminate proletarian union practically by developing special kinds of apparatus-regimes in which the poor can be corralled in a way that prevents the formation of any such effective foamal structures. By creating regimes of internal terrorism, i.e. frightening, isolating, individualising, psychoquarantining practices, individual spheres of agency can be punctured and deflated. Miliband (1974), for instance, notes the powerfully depoliticising, hope-draining properties of welfare. Neoliberal workfare is an acute extension and intensification of this agency deflation effect, prosecuted on an institutional basis against the sufferers of poverty. One sees this physically in a workfare centre in the deflated body language of its victims. Thus deflated, groups can be held in a state of "sloppy foam": that is, in states unconducive to a coagulation into effective unions of resistance - or what I label a negative individualisation experience. As the agency of the internees further deflates under the weight of corroded morale, the staff continue to perceive instead low selfesteem - not recognising that it is workfare itself that adds the personally intolerable to the structurally unbearable. And so the regime of class-racist psychologism and selfdeluding social nurse fantasies self-justifies and repeats.

To say what, precisely, is the point of all of this requires some careful disambiguation. Workfare is a fractious, changeable policy, the ultimate outcome of which may be varied and contradictory. Purpose, in this sense, needs to be mapped as far as possible in real time, or post facto, in order to maintain a grip on workfare's active dialectic responsiveness to changing material and ideological factors. This is where many studies of workfare drift awry; workfare is not one destination in itself, such as superexploitation or social imprisonment. It is, rather, at one and the same time, the train ride to the destination and the means by which its passengers are made to seem like they really belong wherever they are being sent. To achieve this illusion, it is not really ideology that is deployed so much as what Habermas (1976: 15) has described as "not-learning" - i.e. the cynical disruption of coherent thought. The masterpiece of not-learning is the concept of the underclass - not so much the word, which is merely a twisted signifier, but its implication of a cellular plural. Via this term, the structural root of poverty is aggressively downloaded into its victims, and then, by legerdemain, transubstantiated into them, as people, courtesy of mythologies of personal dysfunction. Process becomes people - an act of rhetorical magic, complete with its own fairy-tale characters: fecklemes. Fecklemes become blame sponges, swelling semiotically as all aspects of their life become resignified into attractors of opprobrium - an anathattractive state. Physical compression via economic processes and state apparatuses, and discursive compression via class-racist discourse, then merges these swollen sponges via mendacious social rhyming. The victims of poverty are thus made to appear as a culture - almost as an ethnicity with shared (dysfunctional) mores. This has to happen because structural poverty is massive, and so laundering it into simple individual dysfunction could never mask the sheer scale of it. For the laundering to work, individual dysfunction has to be - somehow - scaled back up to the size of the real problem. The genius of the capitalist episteme is to solve this by simply eliminating the coherent distinction between individual, plural and process via the concept of the dysfunctional underclass. Individual anathattractive states are thus amalgamated into the Anathattractive State (the underclass) a social cancer, each cell of which is re-signified to appear as the fractal carrier of an entire cultural pathology.

This transubstantiation of processes into people is a Devil's arithmetic which cannot be captured as a coherent thought, but only by such. It requires its own sign: The Anathattractive s/State. This signifies the illusion via which secondment to an individual anathattractive state is simultaneously one's re-signification into a metonymic fractal of a mythical filth-column State. 
PJOS 5(2), 2013

Where this project is heading is open to question. Marx (1975b) notes that capitalist ideology falsely fractures perceptions of society to create the illusion of differential social limbs which thus appear systemically unconnected, and thriving according to their own internal circulatory systems. The Anathattractive s/State is a step beyond, to a deliberately prosecuted alien limb syndrome, in which the victims of structural poverty are transformed into a diseased extremity. This, as Wright (1997) has rightly pointed out, is a dangerous conceit which, in time, might even lead to calls for amputation.

\subsection{Programmatic implications}

This paper reiterates the importance of accounting for the grooming effects economic processes have on micro-level symbolism. It particularly highlights the dialectic interplay between mundane economic imperatives - such as low budgets - and glib class-racism in fields associated with the current cultural folk-devil "the underclass". In contrast to many previous studies of "welfare reform", which have tended to present workfare solely in terms of the mass flexibilisation of labour, this paper foregrounds the active and performative nature of symbolic defamation, showing how individuals come to "play out" the role of "feckless unemployed" simply to survive the very processes putatively set in place to "help and support" them back into work. This approach provides a programmatic basis for future explorations of how massive economic events can, in certain institutions, be hypostatised into micro-physical symbolism.

\subsection{Post-Script}

When FND was cancelled in 2010, it had achieved a success rate (that is people gotten back into work) of 5.6 percent (Centre for Economic and Social Inclusion 2012: 1). That is, in layperson's terms, a 95 percent failure rate. New Labour, in other words, did not create much new labour. FND was replaced by the Conservative/Liberal-Democrat coalition's Work Programme in 2011 - an almost identical scheme, but for the name. The expansion of the reserve labour army in order to boost profit continues to be a primary objective of the neoliberal project.

\section{Acknowledgements}

I would like to express my gratitude to Dr. Susie Jacobs, Dr. Kathryn Chadwick, Jacqueline Eke and Professor Jordan Zlatev for their invaluable help and support. I would also like to thank Professor Berthold Schoene and the Institute of Humanities and Social Science Research at Manchester Metropolitan University for their generous funding of my research. In memory of Jock Young. 


\section{References}

Althusser, L. (1971). "Philosophy as a Revolutionary Weapon" in New Left Review. Louis Althusser Archive. URL: http://www.marxists.org/reference/archive/althusser/1968/philosophy-as-weapon.htm Anderson, P. (1983). In the Tracks of Historical Materialism. London: Verso Editions. Archer, M. S. (1989). Culture and Agency; the Place of Culture in Social Theory. Cambridge: Cambridge University Press.

Atkinson, J. (2013). "We Get $£ 17,680$ a year in benefits, buy 40 cigs a day, have a laptop and a home with 47-inch TV. Why work?" in The Sun. 27/1/13.

Balibar, É. (1992). "Class Racism” in Balibar, É. \& Wallerstein, I. [Eds.]. (1992). Race, Nation, Class: Ambiguous Identities. London: Verso.

Bane, M. J. \& Ellwood, D. T. (1994). Welfare Realities: From Rhetoric to Reform. London: Harvard University Press.

Barthes, R. (1988). The Semiotic Challenge. Oxford: Basil Blackwood Ltd.

Bauman, Z. (2000). Liquid Modernity. Cambridge: Polity Press.

Bentham, J. (1791). Panopticon.

BBC (2009). Outrage over teenage father case. BBC News Channel. URL: http://news.bbc.co.uk/1/hi/7889033.stm

Bentham, J. (2010) [1796]. Management of the Poor. Gale Ecco Online Publishers.

Bentham, J. (1843). Outline of a Work Entitled Pauper Management Improved. The Online Library of Liberty.

Berlin, I. (1958). Four Essays on Liberty. Oxford: Oxford University Press.

Bhagwati, J. (2004). In Defense of Globalisation. Oxford University Press.

Black, D. \& Morris, J. N. \& Smith, C. \& Townsend, P. (1990). The Black Report, in Townsend, Peter \& Davidson, Nick [eds.] (1990) Inequalities in Health. Penguin Books Ltd.

Black, T. (2008). "Is it P for Prole?" in Spiked. URL: http://www.spikedonline.com/newsite/article/5936\#.UeKHAW3eLIQ

Blair, T. (1997). Welfare Reform: Giving People the Will to Win. Speech transcript available from Accessmylibrary.com URL: http://www.accessmylibrary.com/article1G1-19897784/welfare-reform-giving-people.html

Bourdieu, P. (1998). Acts of Resistance: Against the new Myths of Our Time. Cambridge: Polity Press.

Bourdieu, P. (2005). The Social Structures of the Economy. Cambridge: Polity Press.

Bourdieu, P. \& Passeron, J. (1990). Reproduction in Education, Society and Culture. London: Sage Publications.

Bret, C. (2003). "Bunching, Time Constraints and Workfare" in Journal of Public Economic Theory. Vol. 7 No. 1, pp 93-105.

Bryner, G. (1998). The Great American Welfare Reform Debate: Politics and Public Morality. London: W. W. Norton and Company.

Burnett, J. (1994). Idle Hands. London: Routledge.

Byrne, D. (2005). Social Exclusion. [Second edition]. Buckingham: Open University Press.

Cameron, A. \& Palan, R. (2004). The Imagined Economies of Globalization. London: Sage Publications.

Cameron, D. (2009). Putting Britain Back on Her Feet. Conservative Party Online. URL: http://www.conservatives.com/News/Speeches/2009/10/David Cameron Putting Brit ain back on her feet.aspx 
PJOS 5(2), 2013

Cameron, D. (2013). "Crazy situation where you earn more on benefits than you do at work ends NOW" in The Sun. 7/4/13.

Centre for Economic and Social Inclusion. (2012). Work Programme Performance Statistics: Inclusion Analysis. Centre for Economic and Social Inclusion. URL: http://stats.cesi.org.uk/website documents/initial WP Performance InclusionComme nt.pdf

Cohen, G. A. (1978). Karl Marx's Theory of History: A Defence. Oxford: Clarendon Press.

Daguerre, A. (2004). "Importing Workfare: Policy Transfer of Social and Labour Market Policies form the USA to Britain Under New Labour" in Social Policy and Administration. Vol. 38 No. 1, pp 41-56

Daily Mail. (2012). "Millionaire lifestyle of benefit fraudster: jailed, the company director who fiddled more than $£ 118,000$ " in The Daily Mail. Mail online. URL: http://www.dailymail.co.uk/news/article-1292445/Benefit-fraudster-John-Watkinsonjailed-fiddling-118k.html

Danaher, G. \& Webb, J. \& Schirato, T. (2000). Understanding Foucault. London: Sage Publications.

Deane, P. (1978). The Evolution of Economic Ideas. Cambridge University Press.

Department for Work and Pensions. (2008). A Comparative Review of Workfare Programmes in the United States, Australia and Canada. HM Government.

Department for Work and Pensions. (2009). Flexible New Deal Guidance: Section 12 Financial Procedures. HM Government.

Department for Work and Pensions. (2012). Community Action Programme: Provider Guidance. HM Government.

Digby, A. (1989). British Welfare Policy: Workhouse to Workfare. London: Faber and Faber.

Donlan, T. C. (2008). A World of Wealth: How Capitalism Turns Profits Into Progress. Harlow: Financial Times \& Prentice Hall.

Dostal, J. M. (2008). "The Workfare Illusion: Re-Examining the Concept and the British Case" in Social Policy and Administration. Volume 42 No. 1, pp. 19-42.

Douglas, M. (1969). Purity and Danger: An Analysis of Concepts of Pollution and Taboo. London: Routledge \& Kegan Paul.

Dumenil, G. \& Levy, D. (2004). Capital Resurgent: Roots of the Neoliberal Revolution. Harvard University Press.

Eagleton, T. (1991). Ideology: an Introduction. London: Verso.

Engels, F. (1976) Ludwig Feuerbach and the End of Classical German Ideology. Peking: Foreign Language Press.

Esping-Anderson, G. (1990). The Three Worlds of Welfare Capitalism. Cambridge: Polity Press.

Foucault, M. (1991). Discipline and Punish. London: Penguin Books Ltd.

Gans, H. J. (1995). The War Against the Poor: The Underclass and Antipoverty policy. New York: Basic Books.

Gilder, G. (1982). Wealth and Poverty. London: Buchan \& Enright Publishers Ltd.

Goffman, E. (1961). Asylums. London: Penguin Books Ltd.

Goffman, E. (1990). Stigma. London: Penguin Books Ltd. 
Goldberg, C. A. (2001). "Welfare Recipients or Workers? Contesting the Workfare State in New York City" in Sociological Theory. Vol. 19 No. 2, pp. 187-218.

Gorz, A. (1989). Critique of Economic Reason. London: Verso.

Habermas, J. (1976). Legitimation Crisis. London: Heinemann Educational Books Ltd.

Handler, J. F (1995). The Poverty of Welfare Reform. New Haven: Yale University Press.

Harvey, D. (2011). The Enigma of Capital and the Crises of Capitalism. London: Profile Books Ltd.

Hawkes, T. (1977). Structuralism and Semiotics. London: Methuen and Co. Ltd.

Hazlitt, W. (1807). Malthus and the Liberties of the Poor. Available online at: http://www.blupete.com/Literature/Essays/Hazlitt/MalthusReply.htm

Herd, D. \& Mitchell, A. \& Lightman, E. (2005). "Rituals of Degradation: Administration as Policy in the Ontario Works Programme" in Social Policy and Administration. Vol. 39 No. 1, pp. 65-79.

Hohmeyer, K. \& Wolff, J. (2012). "A Fist Full of Euros: Is the German One-Euro Job Workfare Scheme Effective for Participants?" in International Journal of Social Welfare. Vol. 21 No. 2, pp. 174-185.

Hunter, R. \& De Simone, T. (2009). "Identifying Disadvantage: Beyond Intersectionality" in Grabham, E. \& Cooper, D. \& Krishnadas, J. \& Herman, D. [Eds.]. (2009). Intersectionality and Beyond; Law, Power and the Politics of Location. Abingdon: Routledge-Cavendish. Pp. 159-177.

Jameson, F. (1991). Postmodernism, or, The Cultural Logic of Late Capitalism. London: Verso.

Jessop, B. (1993). "Towards a Schumpeterian Workfare State? Preliminary Remarks on Post-Fordist Political Economy" in Studies in Political Economy (1993). Vol. 40, spring edition, pp. 7-40.

Jewish Virtual Library. (2013). Badge, Jewish. The American-Israeli Cooperative Enterprise.

Jones, C. and Novak, T. (1999). Poverty, Welfare and the Disciplinary State. London: Routeledge.

Jones, O. (2011). Chavs: The Demonization of the Working Class. London: Verso.

Kafka, F. (1953). The Trial. Harmondsworth: Penguin Books Ltd.

Kennedy, J. F. (1962). Special Message to the Congress on Public Welfare Programs. The American Presidency Project. Available online at: http://www.presidency.ucsb.edu/ws/?pid=8758/

Keynes, J. M. (1997). The General Theory of Employment, Interest and Money. New York: Prometheus.

Klein, N. (2007). The Shock Doctrine: the Rise of Disaster Capitalism. London: Penguin Books Ltd.

Kreiner, C. T. \& and Tranoes, T. (2005). "Optimal Workfare with Voluntary and Involuntary Unemployment" in The Scandinavian Journal of Economics. Vol. 107 No. 3, pp. 459-474.

Layard, R. \& Nickell, S. \& Jackman, R. (1994). The Unemployment Crisis. Oxford: Oxford University Press.

Leeuwen, T. V. (2005). Introducing Social Semiotics. London: Routledge.

Levi-Strauss, C. (1961). Triste Tropiques. New York: Criterion Books.

Littlejohn, R. (2008). "Welcome to Britain, Land of the Rising Scum" in The Mail Online. URL: http://www.dailymail.co.uk/news/article-1085518/RICHARDLITTLEJOHN-Welcome-Britain-land-rising-scum-.html

Littlewood, M. (2013) "Why Osborne must publish the names of every benefits claimant - and how much we pay them: An incendiary idea to save on our $£ 500 m$ A DAY welfare bill" in Daily Mail. 23/7/13. 
PJOS 5(2), 2013

Lukacs, G. (1971). History and Class Consciousness: Studies in Marxist Dialectics. London: The Merlin Press Ltd.

Macnicol, J. (1994). "Is There an Underclass? The Lessons From America" in White, M. [ed]. (1994). Unemployment, Public Policy and the Changing Labour Market. London: Policy Studies Institute.

Mandel, E. (1971). Marxist Economic Theory. London: Merlin Press.

Manning, P. (1992). Erving Goffman and Modern Sociology. Cambridge: Polity Press.

Marcuse, H. (1963). One Dimensional Man: Studies in the Ideology of Advanced Industrial Society. London: Routledge.

Marx, K. (1887). Capital: A Critique of Political Economy [First English edition of 1887, Soviet edition, originally published by: Moscow: Progress Publishing Ltd., published online by Marxists.org 2010].

Marx, K. (1975a) [1865]. Wages, Price and Profit. Peking: Foreign Languages Press.

Marx, K. (1975b) [1847]. The Poverty of Philosophy. Moscow: Progress Publishers.

Mead, L. (1986). Beyond Entitlement. London: Collier Macmillan Publishers Ltd.

Mead, L. (2005). "Welfare Reform and Citizenship" in Mead, L. \& Beem, C. [Eds.]. (2005). Welfare Reform and Political Theory. New York: Russell Sage Foundation.

Miliband, R. (1974). "Politics and Poverty" in Wedderburn, D. [ed.]. (1974). Poverty, Inequality and Class Structure. Cambridge University Press.

Miliband, R. (1989). Divided Societies: Class Struggle in Contemporary Capitalism. Oxford University Press.

Mill, J. (1808). On the Overproduction and Underconsumption Fallacies. Edited by George Reismann (2006). The Jefferson School of Philosophy, Economics and Society. URL: http://www.capitalism.net/Jamesmil.pdf

Mill, J. S. (1998) On Liberty. Pennsylvania: Pennsylvania State University Press.

Moynihan, D. P. (1965). The Negro Family: The Case for National Action. Office of Policy Planning and Research, United States Department of Labor. Published by Blackpast.org; available online at: http://www.blackpast.org/?q=primary/moynihanreport-1965

Murray, C. (1984). Losing Ground: American Social Policy 1950-1980. New York: Basic Books Inc.

Murray, C. (1996). "The Emerging British Underclass" in Lister, R. (ed). (1996). Charles Murray and the Underclass; the Developing Debate. London: The IEA Health and Welfare Unit.

Murray, D. (2013). "The Philpott case should prompt debate about Britain's underclass" in The Spectator. 4/4/13.

Murray, P. (2013). "Payment-by-Results Privatisation Would be "Disastrous" for Probation Service" in UnionNews.co.uk May 2013. URL: http://unionnews.co.uk/2013/05/race-to-the-bottom-warning-over-probationprivatisation/\#sthash.DB0ENcF1.dpuf

National Audit Office (2012). The Introduction of the Work Programme. Department for Work and Pensions. HM Government.

Nozick, R. (1974). Anarchy, State, And Utopia. [1996 reprint] Oxford: Blackwell Publishers Ltd. 
Overbeek, H. \& Pijl, K. (1993). "Restructuring Capital and Restructuring Hegemony" in Overbeek, H. (ed). (1993). Restructuring Hegemony in the Global Political Economy: The Rise of Transnational Neoliberalism in the 1980s. London: Routledge.

Pakulski, J. \& Waters, M. (1996). The Death of Class. London: Sage Publications.

Peck, J. (1998). "Postwelfare Massachusetts" in Economic Geography. Vol. 74. No. 1, pp. 62-82.

Peck, J. (2001). Workfare States. New York: The Guildford Press.

Peck, J. (2002) ."Political Economies of Scale: Fast Policy, Interscalar Relations, and Neoliberal Workfare" in Economic Geography. Vol. 78 No. 3, pp. 331-360.

Piven, F. F. (1998). "Welfare Reform and the Economic and Cultural Reconstruction of Low Wage Labour Markets" in City and Society. (1998) Vol. 10 No. 1, pp. 21-36.

Piven, F. F. and Cloward, R. (1971.) Regulating the Poor: The Functions of Public Welfare. London: Tavistock Publications Limited.

Piven, F. F. and Cloward, R. (2001) "Foreword" in Peck, J. (2001). Workfare States. New York: The Guildford Press.

Quaid, M. (2002). Workfare: Why Good Social Policy Turns Bad. University of Toronto Press Incorporated.

Rand, A. (1964). The Virtue of Selfishness: A New Concept of Egoism. The Objectivist Newsletter Inc.

Sartre, J. P. (2004). Critique of Dialectical Reason. Volume One: Theory of Practical Ensembles. London: Verso.

Schwartz, J. (2005). "PWORA and the Promotion of Virtue" in Mead, L. \& Beem, C. [Eds.]. (2005). Welfare Reform and Political Theory. New York: Russell Sage Foundation.

Skeggs, B. (2004). Class, Self, Culture. London: Routledge.

Smith, I. D. (2008). "Mend Broken Homes to End Tragedy" in The Guardian, 13/11/2008. URL: http://www.theguardian.com/commentisfree/2008/nov/13/baby-pdysfunctional-families

Spicker, P. (1984). Stigma and Social Welfare. London: St. Martin's Press.

Sunley, P. \& Martin, R. \& Nativel, C. (2001). "Mapping the New Deal: Local Disparities in the Performance of Welfare-to-Work" in Transactions of the Institute of British Geographers. Vol. 26 No. 4, pp. 484-512.

Volosinov, V. N. (1986 [1929]). Marxism and the Philosophy of Language. London: Harvard University Press.

Wacquant, L. (2010). "Crafting the Neoliberal State: Workfare, Prisonfare, and Social Insecurity" in Sociological Forum. Vol. 25 No. 2, pp. 197-210.

Wax, A. L. (2005). "The Political Psychology of Redistribution" in Mead, L. \& Beem, C. [Eds.]. (2005). Welfare Reform and Political Theory. New York: Russell Sage Foundation.

Wheeler, B. (2005). "Who are Britain's Hardworking Families?" British Broadcasting Corporation

(BBC).

URL:http://news.bbc.co.uk/1/hi/uk politics/vote 2005/frontpage/4458273.stm

Weathers, H. (2009). "What made Baby P's mother Tracey Connelly so wicked?" in The Mail Online 14/8/2009. URL: http://www.dailymail.co.uk/news/article1206629/What-Baby-Ps-mother-Tracey-Connelly-wicked.html

West, E. (2009). "The welfare state, not social workers, sealed the fate of baby P" in The Telegraph Online. URL: http://blogs.telegraph.co.uk/news/edwest/9710277/the_welfare_state_not_social_work ers_sealed_the_fate_of_baby_p/

Westergaard, J. (1995). Who Gets What? The Hardening of Class Inequality in the Late Twentieth Century. Cambridge: Polity Press. 
PJOS 5(2), 2013

Woods, J. (2009). "Alfie Patten - the exploited face of broken Britain" in The Telegraph 16/2/2009. URL: http://www.telegraph.co.uk/news/features/4642363/Alfie-Patten-theexploited-face-of-broken-Britain.html

Wright, E. O. (1997). Class Counts: Comparative Studies in Class Analysis. Cambridge University Press. 